\title{
Dynamic Seismic Analysis and Design of R.C.C Multi Purpose Building (G+15) By using E-Tabs
}

\author{
T.G.N.C. Vamsi Krishna, V. Amani, P.S. Sunil Kumar, CH. Naveen Kumar, M.Srinivas
}

\begin{abstract}
An earthquake is a sudden, rapid shaking of the earth caused by the breaking and shifting of rock beneath the earth's surface. Earthquakes are among the most powerful events on earth, and their results can be terrifying. In general for design of tall buildings both wind as well as earthquake loads need to be considered. Governing criteria for carrying out dynamic analyses for earthquake loads are different from wind loads. However many tall buildings are not so resistant in lateral loads due to earthquake. Reinforced concrete multi-storied buildings in India were for the first time subjected to a strong ground motion shaking in Bhuj earthquake. It has been concluded that the principal reasons of failure may be attributed to soft stories, floating columns, mass irregularities, poor quality of construction materials faulty construction methods, unstable earthquake response, soil and infrastructure, which were determined to cause damage to the attached structure. High-rise buildings are in high demand due to global urbanization and population growth, and high-rise buildings are likely to suffer the most damage from earthquakes. Since earthquake forces are irregular and unnatural in nature, engineering tools need to be sharpened to analyze the structure in the work of these forces. In this study, to understand the behaviour of structure located in seismic zones III for G+15 Multi-Purpose storey building model is considered for study. Performance of frame is studied through Response Spectrum analysis and comparison is made on shear force, storey drift, storey displacement and storey stiffness.
\end{abstract}

Keywords: Earthquake, analysis, structures, urbanization

\section{INTRODUCTION}

$\mathrm{A}_{\mathrm{n}}$ earthquake is a sudden tremble or movement of the earth's crust which originates naturally at or below the surface. The word regular is vital here, since it prohibits stun waves caused by atomic tests, man-made blasts and so forth. The whole world is comprised of plates.

Manuscript received on August 07, 2021.

Revised Manuscript received on August 25, 2021.

Manuscript published on August 30, 2021.

* Correspondence Author

T.G.N.C. Vamsi Krishna, Assistant Professor, Department of Civil engineering, Chalapati Institute of Engineering and Technology, Lam, Guntur, Andhra pradesh-522002, India.

V. Amani, B.Tech final year, Department of Civil engineering, Chalapati Institute of Engineering and Technology, Lam ,Guntur, Andhra pradesh-522002, India.

P.S. Sunil Kumar*, B.Tech final year, Department of Civil engineering, Chalapati Institute of Engineering and Technology, Lam ,Guntur, Andhra pradesh-522002, India.

CH. Naveen Kumar, B.Tech final year, Department of Civil engineering, Chalapati Institute of Engineering and Technology, Lam ,Guntur, Andhra pradesh-522002, India.

M. Srinivas, B.Tech final year, Department of Civil engineering, Chalapati Institute of Engineering and Technology, Lam ,Guntur, Andhra pradesh-522002, India.

(c) The Authors. Published by Blue Eyes Intelligence Engineering and Sciences Publication (BEIESP). This is an open access article under the CC BY-NC-ND license (http://creativecommons.org/licenses/by-nc-nd/4.0/)
The intersection between the two plates is called as fault. This fault in the Indian Context is the main boundary, fault extending through the terrain region all the way from west along Himachal Pradesh through Uttaranchal, Bihar, Assam to Burma. That plate descends through Andaman-Nicobar Islands and Bay of Bengal and into Indonesia. As the plate moves the rocks are subjected to stress, suddenly a fracture develops and this fracture is called as an earthquake.

In The present study we are using E-tabs software to design the Building in seismic zone III and to different the property and its results.

\subsection{Affect of Earthquakes on Reinforced Concrete Buildings}

A common RC building is made up of members of the floor (beam and slab) and floor members (floor and wall) and is supported by the foundation on the ground. The system consists of an RC frames The RC frame participates in resting the earthquake forces. Earthquake shaking generates inertia forces in the building, which are proportional to the building mass. Since most of the building mass are present at the ground level, the energy generated by the earthquake is mainly developed at the ground level. These energies go down - through the slabs and beams to the pillars and walls, and then from the foundation to the ground. As the inactive energy accumulates from the top of the building, the pillars and walls of the ground floor experience more earthquake power and are therefore designed to be more powerful than the people on the upper floor.

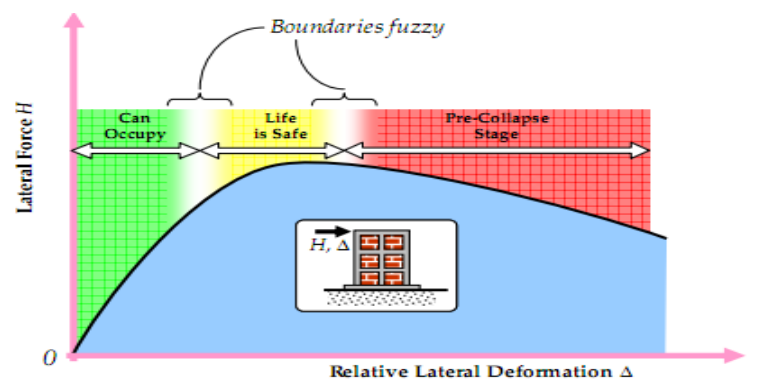

Figure 1. Seismic Performance of the building.

\subsection{Seismic Zone Map of India \& Recent Earthquakes}

Earthquakes have been occurring in the Indian subcontinent from the time immemorial but reliable historical records are available for the last 200 years (Oldham,1883). From the beginning of the $20^{\text {th }}$ century, more than 700 earthquakes of magnitude 5 or more have been recorded and felt in India. The seismicity of India is divided into four groups, namely Himalayan region, Andaman Nicobar, Kutch Region, and Peninsular India. 
The goal of seismic zoning is to delineate regions of probable intensity of ground motion in a country, for providing a guideline for provision of an adequate earthquake resistance in constructed facilities. The first comprehensive seismic zoning map was developed by the Bureau of Indian Standards in 1962. Later in the subsequent years it was reviewed many times and thus a four zone seismic zoning map was adopted in Is 1893:2002. The map is based on expected intensity of ground shaking but does not consider the frequency of the occurrence. Current seismic zoning map as per IS 1893-2002 says that around $60 \%$ (Zone V= 12\%, Zone IV=18\%, Zone III $=26 \%$ and Zone II 44\%) of India is prone to moderate to major earthquakes. Accordingly, zone factors (z) are defined for each zone to arrive at the design seismic force acting on the structure. Zone II corresponds to intensity VI or lower and zone $\mathrm{V}$ corresponds to intensity IX or higher. Zone II has lowest danger or risk while Zone - V has highest hazards. Since damage controlled limit state has been accepted, the zone factor, $\mathrm{z}$ has been reduced to half ( $\mathrm{z} / 2$ ) of Maximum Considered Earthquake (MCE) for Design Basis Earthquake (DBE).Structures are explicitly designed for DBE and maximum considered earthquake is taken care of through over strength and ductility provisions.

Table 1: Showing the number of zones in different years.

\begin{tabular}{|c|c|c|c|}
\hline \multicolumn{4}{|c|}{ Year of Release of Zone Maps } \\
\cline { 1 - 2 } $\mathbf{1 9 6 2}$ & $\mathbf{1 9 6 6}$ & $\mathbf{1 9 8 4}$ & $\mathbf{2}$ \\
\hline 0 & 0 & I & \multirow{2}{*}{ II } \\
\hline I & I & II & \\
\hline II & II & III & III \\
\hline III & III & VI & IV \\
\hline IV & IV & V & V \\
\hline V & V & VI &
\end{tabular}

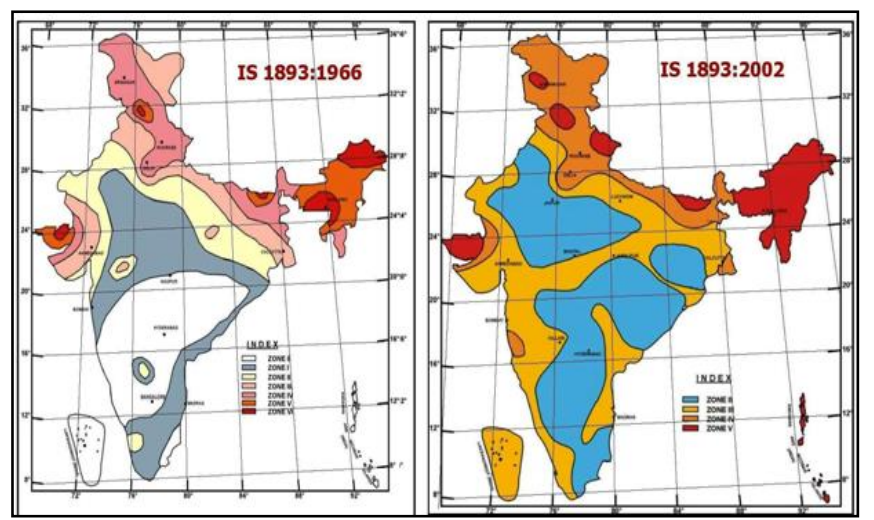

Figure 2: Seismic zoning maps of India I.S. 1893:1966 and IS1893:2002

\section{LETERATURE REVIEW}

Balaji U \& Selvarasan in 2012 studied the G +13 storey residential building. The building was analyzed for earthquake load using ETABS. The properties of the material were assumed to be simple and stable and dynamic analysis was performed. These non-linear analyzes were carried out with a second type of soil condition in view of the severe earthquake area and behavioural assessment. Different reactions such as displacement and base shear

were calculated and it was found that displacement increases with building height.

Mahesh N. Patil, Yogesh N. Sonawane studied the seismic analysis of an 8-story building in 1998. $22.5 \mathrm{~m} \mathrm{x}$ 22.5-m, multi-storey common structure considered for study. Floor to floor height is considered as $3 \mathrm{~m}$. Modelling and analysis of the structure is done in ETABS software The structure is analyzed and the results generated by the software are compared with the manual analysis of the structure using IS 1893: 2002.

The. Mahesh, B. Pandurangarao and others studied residential buildings of normal and irregular structures $(\mathrm{G}+$ 11) for earthquakes and wind loads using 2008 ETABS and staad pro V8i. Material property is considered to be static, dynamic and dynamic analysis for different seismic zones and for each zone; Behaviour was assessed using three different types of soils, namely hard, medium and soft. The authors have compared the general and irregular structures to the following theories,

- The base shear standards and story drift values were more in regular configuration than irregular configuration.

- $\quad$ Base shear value was more in the zone 5 and that in the soft soil in regular configuration.

- Story drift value was more in the story 13 in the regular configuration.

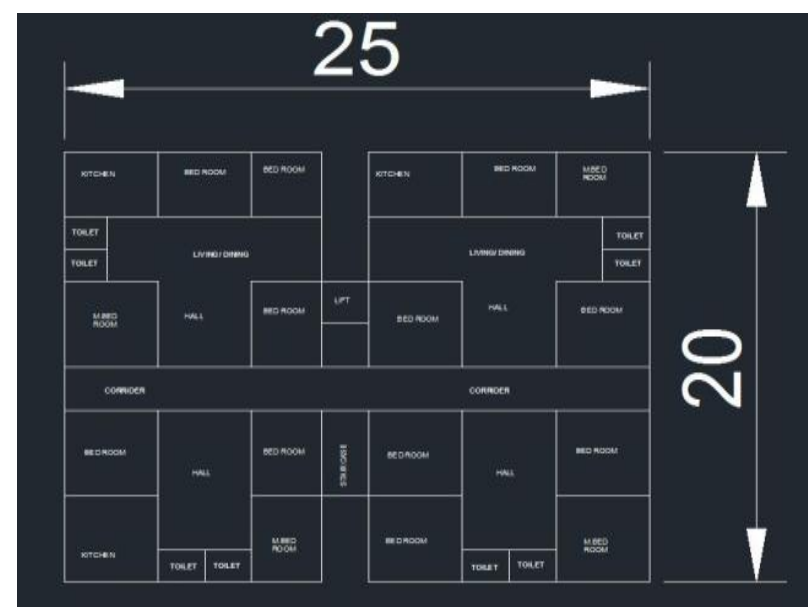

Figure 3. Residential floor plan for second to 15th floor

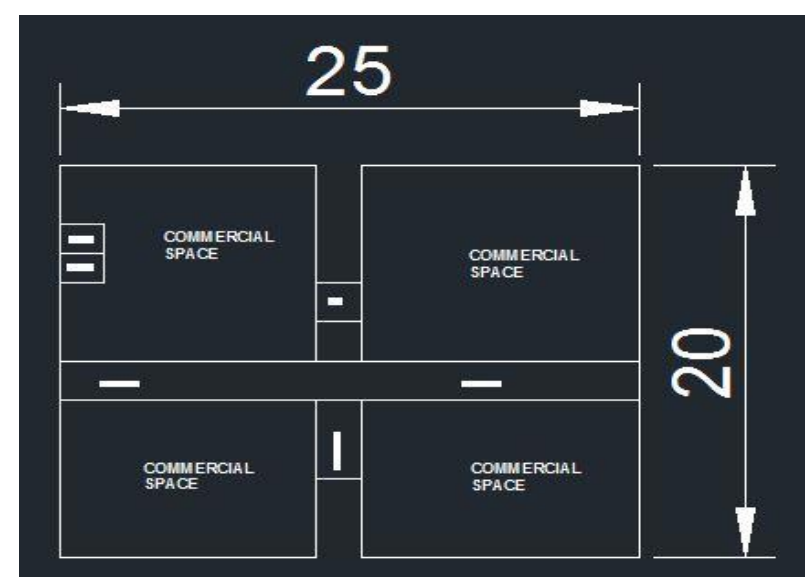

Figure 4. commercial floor plan for ground and 1st floor

Blue Eyes Intelligence Engineering and Sciences Publication (C) Copyright: All rights reserved.

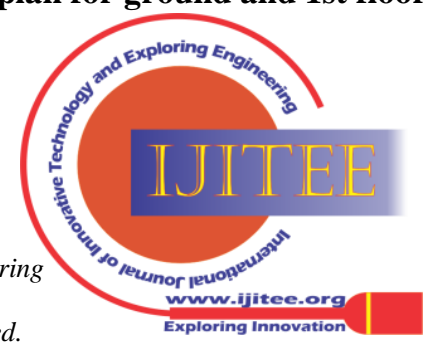




\section{MODELING}

3.1 Structural Modelling Of G+15 Floor Rcc Building

Table 2: Showing the properties taken into consideration for modelling the structure

\begin{tabular}{|c|c|c|}
\hline Type & Residential & Commercial \\
\hline `Live Load & $2 \mathrm{KN} / \mathrm{m} 2$ & $3 \mathrm{KN} / \mathrm{m} 2$ \\
\hline $\begin{array}{c}\text { Floor finish and } \\
\text { ceiling load }\end{array}$ & $2 \mathrm{KN} / \mathrm{m} 2$ & $2 \mathrm{KN} / \mathrm{m} 2$ \\
\hline $\begin{array}{l}\text { Density of RCC } \\
\text { considered: }\end{array}$ & $25 \mathrm{kN} / \mathrm{m} 3$ & $25 \mathrm{kN} / \mathrm{m} 3$ \\
\hline $\begin{array}{l}\text { Height of the } \\
\text { structure }\end{array}$ & $55.65 \mathrm{~m}$ & $55.65 \mathrm{~m}$ \\
\hline $\begin{array}{c}\text { Thickness of } \\
\text { slab }\end{array}$ & $125 \mathrm{~mm}$ & $150 \mathrm{~mm}$ \\
\hline $\begin{array}{l}\text { Grade of } \\
\text { Concrete }\end{array}$ & M25 & M25 \\
\hline Depth of beam & $480 \mathrm{~mm}$ & $480 \mathrm{~mm}$ \\
\hline Width of beam & $300 \mathrm{~mm}$ & $300 \mathrm{~mm}$ \\
\hline $\begin{array}{c}\text { Dimension of } \\
\text { column }\end{array}$ & $\begin{array}{l}900 * 600 \mathrm{~mm}, \\
1400 * 600 \mathrm{~mm}\end{array}$ & $\begin{array}{l}900 * 600 \mathrm{~mm}, \\
1400 * 600 \mathrm{~mm}\end{array}$ \\
\hline $\begin{array}{l}\text { Height of each } \\
\text { floor }\end{array}$ & $3.05 \mathrm{~m}$ & $3.05 \mathrm{~m}$ \\
\hline $\begin{array}{l}\text { Depth of } \\
\text { foundation }\end{array}$ & $3 \mathrm{~m}$ & $3 \mathrm{~m}$ \\
\hline $\begin{array}{l}\text { Earthquake } \\
\text { Zone }\end{array}$ & III & III \\
\hline Damping Ratio & $5 \%$ & $5 \%$ \\
\hline $\begin{array}{c}\text { Importance } \\
\text { factor }\end{array}$ & 1 & 1 \\
\hline Type of Soil & Medium soil & Medium soil \\
\hline $\begin{array}{l}\text { Type of } \\
\text { structure }\end{array}$ & $\begin{array}{l}\text { Special Moment } \\
\text { Resisting Frame }\end{array}$ & $\begin{array}{l}\text { Special Moment } \\
\text { Resisting Frame }\end{array}$ \\
\hline $\begin{array}{c}\text { Response } \\
\text { reduction Factor }\end{array}$ & 5 & 5 \\
\hline
\end{tabular}

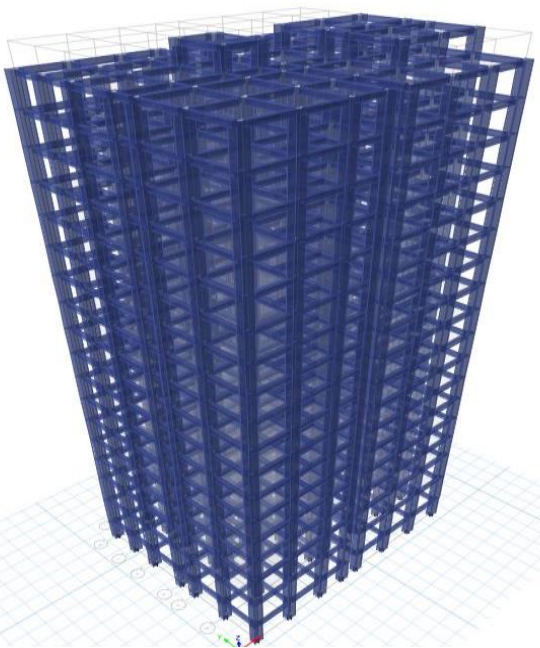

Figure 5. 3D View of structure

\section{ANALYSIS AND RESULTS}

\subsection{Storey Displacement}

The lateral displacement of each story due to the lateral forces from base of the building or structures is known as story displacement. Story displacement results for the structures with various cases for all the models as tabulated below.
Table 3: Storey Displacement of the structure

\begin{tabular}{|l|r|l|r|r|}
\hline \multicolumn{1}{|c|}{ Story } & Elevation & Location & $\begin{array}{c}\text { X- } \\
\text { Dir }\end{array}$ & $\begin{array}{c}\text { Y- } \\
\text { Dir }\end{array}$ \\
\hline $\begin{array}{l}\text { OVER HEAD } \\
\text { WATER } \\
\text { TANK }\end{array}$ & 55.65 & Top & 1.424 & 6.925 \\
\hline $\begin{array}{l}\text { TERRACE } \\
\text { FLOOR }\end{array}$ & 53.65 & Top & 1.121 & 6.598 \\
\hline 15TH FLOOR & 50.6 & Top & 0.963 & 6.048 \\
\hline 14TH FLOOR & 47.55 & Top & 0.839 & 5.494 \\
\hline 13TH FLOOR & 44.5 & Top & 0.736 & 4.945 \\
\hline 12TH FLOOR & 41.45 & Top & 0.645 & 4.406 \\
\hline 11TH FLOOR & 38.4 & Top & 0.562 & 3.883 \\
\hline 10TH FLOOR & 35.4 & Top & 0.486 & 3.387 \\
\hline 9TH FLOOR & 32.35 & Top & 0.414 & 2.905 \\
\hline 8TH FLOOR & 29.3 & Top & 0.346 & 2.449 \\
\hline 7TH FLOOR & 26.25 & Top & 0.284 & 2.024 \\
\hline 6TH FLOOR & 23.2 & Top & 0.227 & 1.631 \\
\hline 5TH FLOOR & 20.15 & Top & 0.176 & 1.276 \\
\hline 4TH FLOOR & 17.1 & Top & 0.131 & 0.961 \\
\hline 3RD FLOOR & 14.05 & Top & 0.092 & 0.689 \\
\hline 2ND FLOOR & 11 & Top & 0.061 & 0.463 \\
\hline 1ST FLOOR & 7.95 & Top & 0.037 & 0.284 \\
\hline $\begin{array}{l}\text { GROUND } \\
\text { FLOOR }\end{array}$ & 3.95 & Top & 0.015 & 0.118 \\
\hline STILT & -0.05 & Top & 0.022 & 0.048 \\
\hline FOUNDATION & -3 & Top & 0 & 0 \\
\hline
\end{tabular}

Result : from the table it is seen that the maximum displacement is occuring at top of the structure at over head tank which is $6.925 \mathrm{~mm}$.

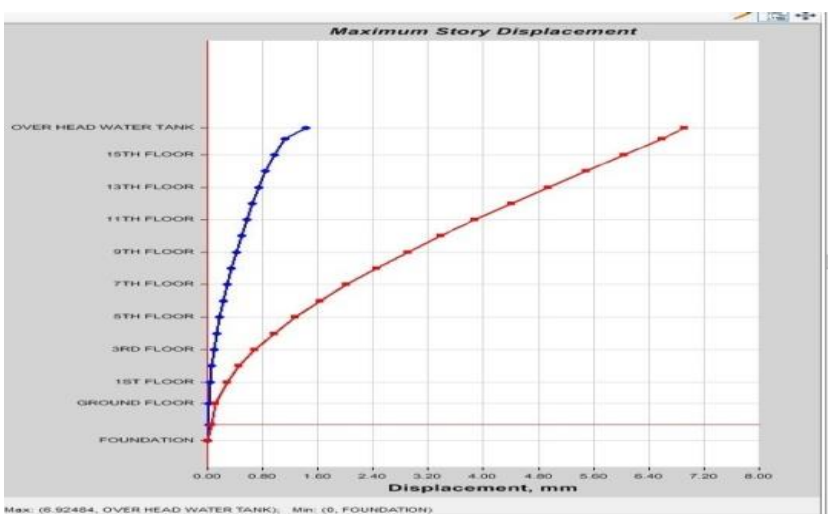

Graph 1: The graph showing the maximum displacement value of the structure.

\subsection{Lateral loads}

Lateral loads are important when facing side loads such as earthquakes and wind loads. The lateral displacement structure depends on the height of the structure and the slenderness of the structure because the lateral load becomes more flexible and the height of the structure becomes weaker and the structure becomes weaker.

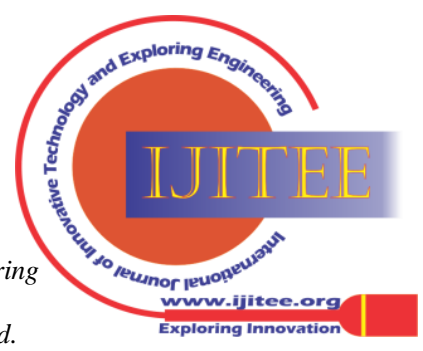


Dynamic Seismic Analysis and Design of R.C.C Multi Purpose Building (G+15) By using E-Tabs

Table 4: Seismic loading of the structure

\begin{tabular}{|c|c|c|}
\hline Story & X-Dir & Y-Dir \\
\hline $\begin{array}{c}\text { OVER HEAD } \\
\text { WATER TANK }\end{array}$ & 29.2898 & 28.6009 \\
\hline TERRACE FLOOR & 141.7423 & 138.4086 \\
\hline 15TH FLOOR & 158.0122 & 154.2959 \\
\hline 14TH FLOOR & 140.5411 & 137.2357 \\
\hline 13TH FLOOR & 124.0933 & 121.1747 \\
\hline 12TH FLOOR & 108.6688 & 106.1129 \\
\hline 11TH FLOOR & 93.9311 & 91.7219 \\
\hline 10TH FLOOR & 80.8111 & 78.9105 \\
\hline 9TH FLOOR & 68.729 & 67.1125 \\
\hline 8TH FLOOR & 57.3807 & 56.0312 \\
\hline 7TH FLOOR & 47.0558 & 45.949 \\
\hline 6TH FLOOR & 37.7541 & 36.8661 \\
\hline 5TH FLOOR & 29.4756 & 28.7824 \\
\hline 4TH FLOOR & 22.2205 & 21.6979 \\
\hline 3RD FLOOR & 15.9886 & 15.6125 \\
\hline 2ND FLOOR & 10.78 & 10.5264 \\
\hline 1ST FLOOR & 7.4912 & 7.315 \\
\hline GROUND FLOOR & 3.2337 & 3.1576 \\
\hline STILT & 0.3281 & 0.3204 \\
\hline FOUNDATION & 0 & 0 \\
\hline
\end{tabular}

Result : from the table it is seen that the maximum lateral loas is occuring at 15th floor which is $154.2959 \mathrm{KN}$ for $\mathrm{x}$-direction and $158.0122 \mathrm{KN}$ for $\mathrm{y}$-direction

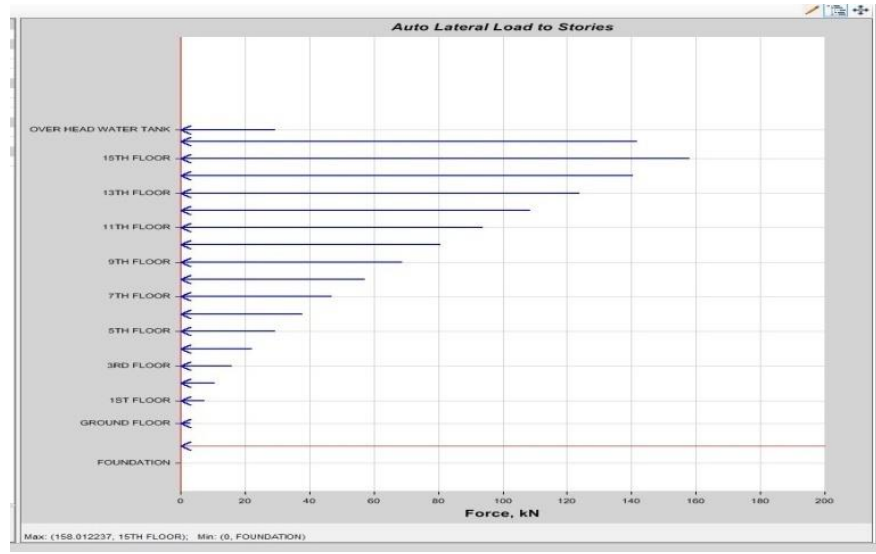

Graph 2: The graph showing the maximum lateral load

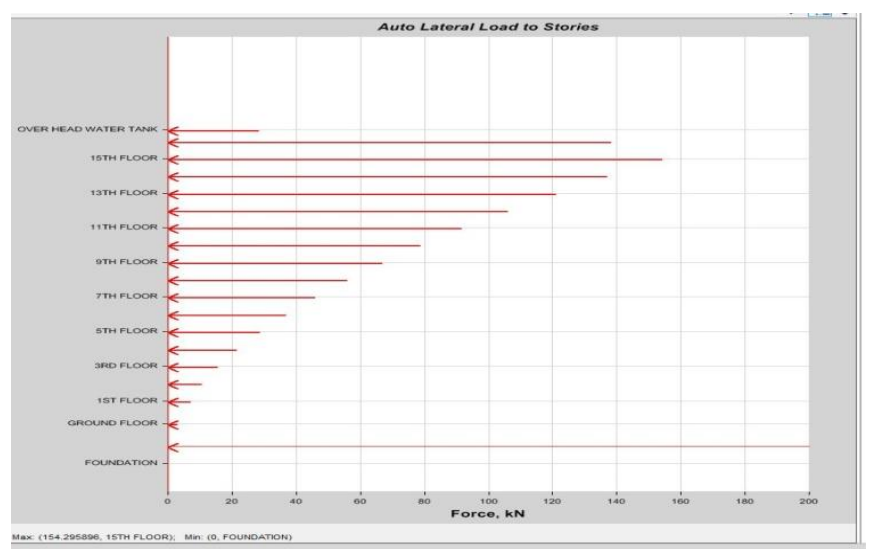

Graph 3: The graph showing the maximum lateral load occuring at $y$-direction. occuring at $\mathrm{x}$ - direction.

Table 5: Wind load on structure

\begin{tabular}{|c|c|}
\hline Story & X-Dir \\
\hline & $\mathrm{kN}$ \\
\hline $\begin{array}{c}\text { OVER HEAD WATER } \\
\text { TANK }\end{array}$ & 40.0989 \\
\hline TERRACE FLOOR & 100.5367 \\
\hline 15TH FLOOR & 120.0549 \\
\hline 14TH FLOOR & 118.4566 \\
\hline 13TH FLOOR & 116.8689 \\
\hline 12TH FLOOR & 115.292 \\
\hline 11TH FLOOR & 112.8021 \\
\hline 10TH FLOOR & 111.2307 \\
\hline 9TH FLOOR & 109.8196 \\
\hline 8TH FLOOR & 106.8007 \\
\hline 7TH FLOOR & 103.7955 \\
\hline 6TH FLOOR & 100.6507 \\
\hline 5TH FLOOR & 97.1567 \\
\hline 4TH FLOOR & 93.0727 \\
\hline 3RD FLOOR & 89.2814 \\
\hline 2ND FLOOR & 88.4672 \\
\hline 1ST FLOOR & 102.2448 \\
\hline GROUND FLOOR & 58.0112 \\
\hline STILT & 0 \\
\hline FOUNDATION & 0 \\
\hline
\end{tabular}

Result : from the table it is seen that the maximum lateral load is occuring at 15th floor which is $120.0549 \mathrm{KN}$ for $\mathrm{x}$-direction

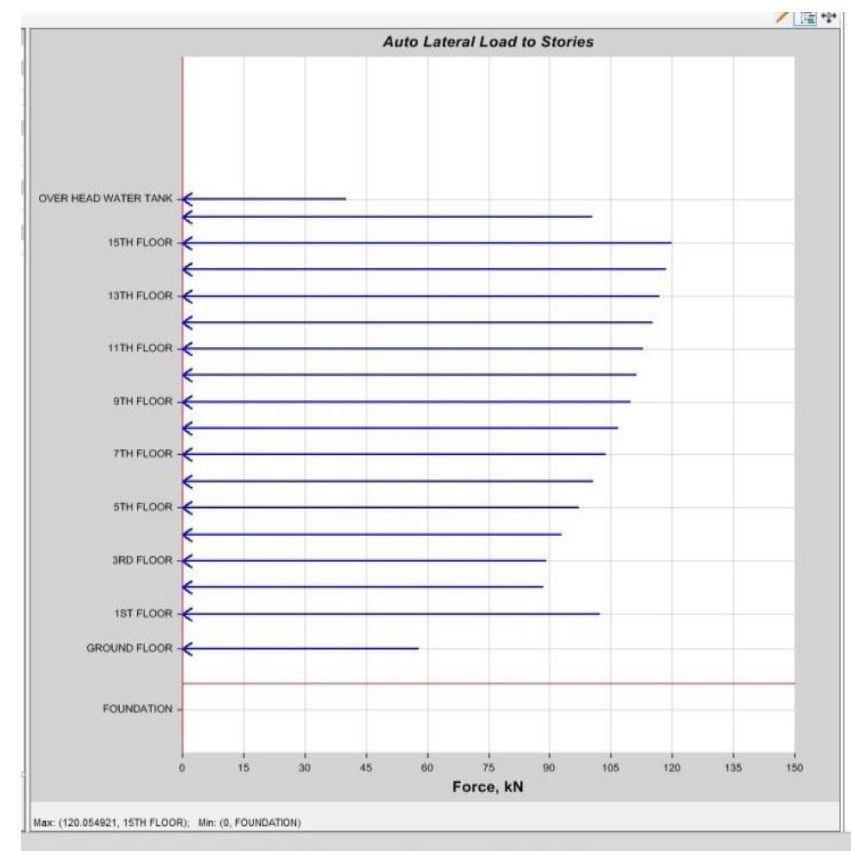

Graph 4: The graph showing the maximum lateral load occuring at $x$ - direction

\subsection{Overturning Moment}

The "overturning moment" at any horizontal plane is the moment on the structure as a whole resulting from the dynamic earthquake forces above the plane, giving due regard to signs of the modal forces.

Published By:

Blue Eyes Intelligence Engineering and Sciences Publication

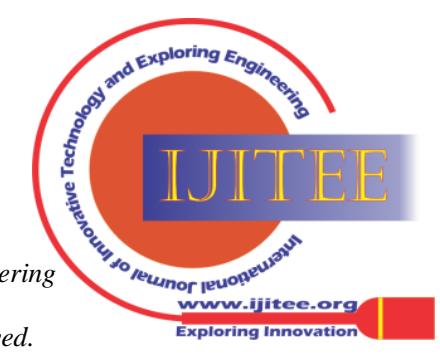


Table 6: overturning moment of the structure

\begin{tabular}{|c|c|c|c|c|}
\hline \multirow[t]{2}{*}{ Story } & \multicolumn{2}{|c|}{ RS-X } & \multicolumn{2}{|c|}{ RS-Y } \\
\hline & X-Dir & Y-Dir & X-Dir & Y-Dir \\
\hline & $\mathrm{kN}-\mathrm{m}$ & $\mathrm{kN}-\mathrm{m}$ & $\mathrm{kN}-\mathrm{m}$ & $\mathrm{kN}-\mathrm{m}$ \\
\hline $\begin{array}{c}\text { OVER HEAD } \\
\text { WATER } \\
\text { TANK }\end{array}$ & 0 & 0 & 0 & 0 \\
\hline $\begin{array}{l}\text { TERRACE } \\
\text { FLOOR }\end{array}$ & 55.9053 & 69.4934 & 30.5932 & 38.029 \\
\hline 15TH FLOOR & 533.9396 & 641.2355 & 292.1889 & 350.9046 \\
\hline 14TH FLOOR & 1390.5539 & 1616.7875 & 760.9557 & 884.7581 \\
\hline 13TH FLOOR & 2500.7158 & 2826.7116 & 1368.472 & 1546.867 \\
\hline 12TH FLOOR & 3758.7967 & 4146.2733 & 2056.934 & 2268.974 \\
\hline 11TH FLOOR & 5106.9736 & 5521.6853 & 2794.7 & 3021.644 \\
\hline 10TH FLOOR & 6511.8768 & 6935.0117 & 3563.508 & 3795.061 \\
\hline 9TH FLOOR & 8034.4758 & 8460.0719 & 4396.723 & 4629.623 \\
\hline 8TH FLOOR & 9658.9213 & 10084.2554 & 5285.672 & 5518.428 \\
\hline 7TH FLOOR & 11377.6761 & 11798.8587 & 6226.23 & 6456.714 \\
\hline 6TH FLOOR & 13180.7623 & 13595.6118 & 7212.936 & 7439.955 \\
\hline 5TH FLOOR & 15066.6029 & 15477.7448 & 8244.929 & 8469.919 \\
\hline 4TH FLOOR & 17038.5877 & 17451.0962 & 9324.063 & 9549.8 \\
\hline 3RD FLOOR & 19094.6614 & 19510.9082 & 10449.21 & 10677 \\
\hline 2ND FLOOR & 21225.2421 & 21643.7782 & 11615.13 & 11844.17 \\
\hline 1ST FLOOR & 23422.9297 & 23843.3131 & 12817.78 & 13047.83 \\
\hline $\begin{array}{l}\text { GROUND } \\
\text { FLOOR }\end{array}$ & 26415.566 & 26848.3418 & 14455.45 & 14692.28 \\
\hline STILT & 29547.3185 & 30015.0122 & 16169.24 & 16425.18 \\
\hline FOUNDATION & 31934.3626 & 32441.7817 & 17475.51 & 17753.18 \\
\hline
\end{tabular}

Result: from the table it is seen that the maximum overturning moment is occuring at foundation level which is the 31934.3626 KN-m at y-direction

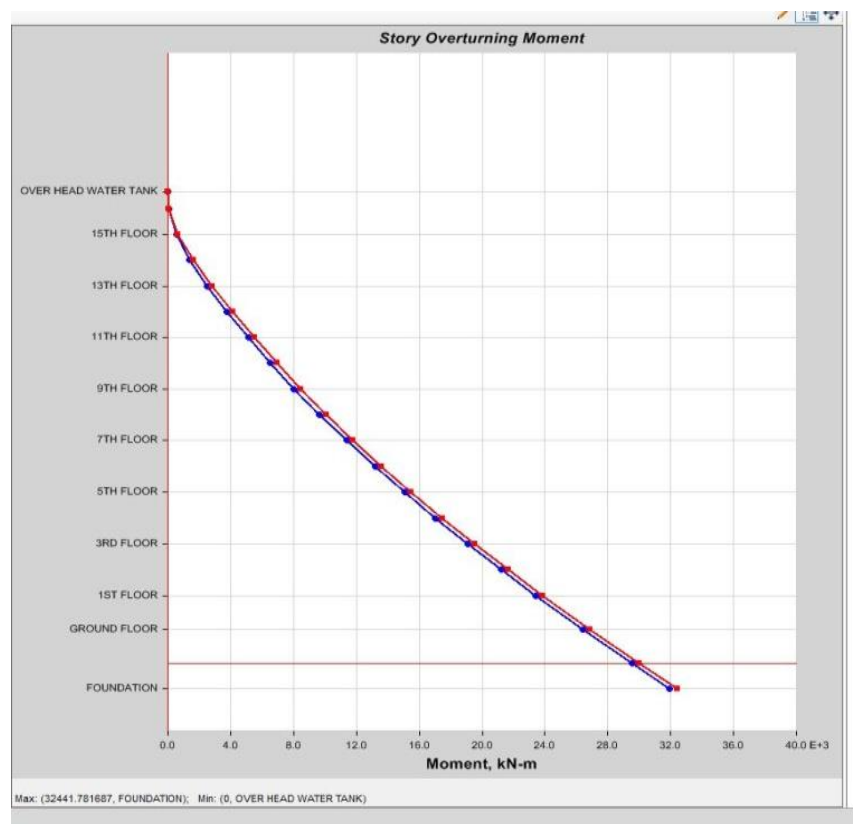

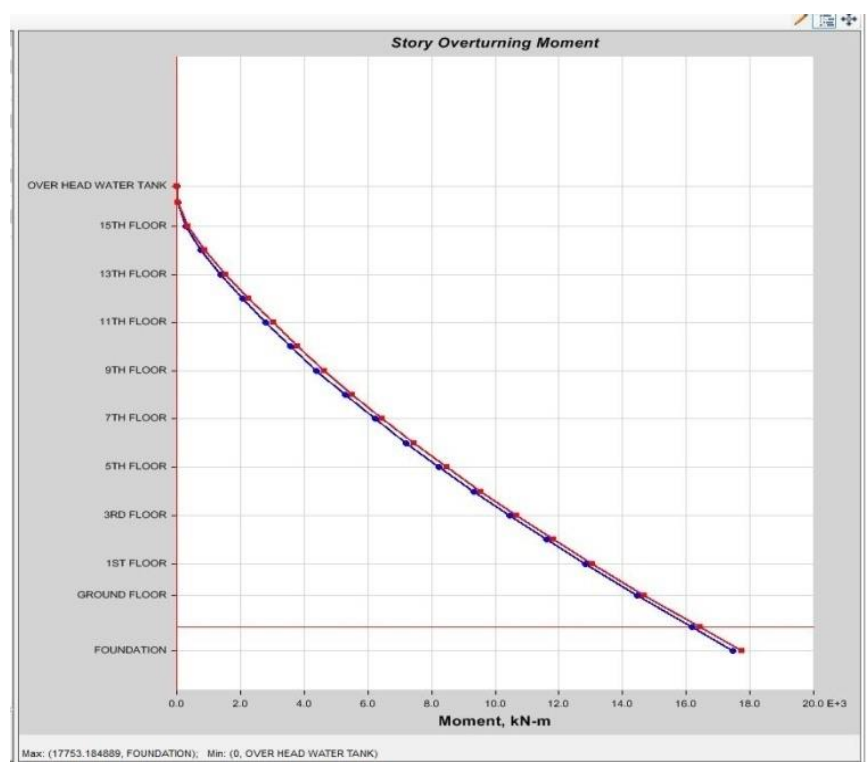

Graph 5 \& 6: The graph showing the maximum overturning moment occurring at $x-y$ direction

\subsection{Storey Stiffness}

Stiffness is the rigidness of any object or material. Objects with a high stiffness will resist changes in shape when being acted on by a physical force

Table 7. Storey Stiffness of the structure

\begin{tabular}{|c|c|c|}
\hline Story & X-Dir & Y-Dir \\
\hline $\begin{array}{c}\text { OVER HEAD } \\
\text { WATER TANK }\end{array}$ & 102516.98 & 115128.213 \\
\hline $\begin{array}{c}\text { TERRACE } \\
\text { FLOOR }\end{array}$ & 299660.196 & 303318.685 \\
\hline 15TH FLOOR & 423752.263 & 409718.143 \\
\hline 14TH FLOOR & 452933.653 & 433864.257 \\
\hline 13TH FLOOR & 448888.275 & 434221.306 \\
\hline 12TH FLOOR & 444187.12 & 433093.293 \\
\hline 11TH FLOOR & 454792.674 & 444670.255 \\
\hline 10TH FLOOR & 450646.801 & 440986.123 \\
\hline 9TH FLOOR & 449719.042 & 443098.129 \\
\hline 8TH FLOOR & 446472.788 & 443463.46 \\
\hline 7TH FLOOR & 446307.73 & 444875.305 \\
\hline 6TH FLOOR & 450977.913 & 449046.733 \\
\hline 5TH FLOOR & 456967.787 & 454185.19 \\
\hline 4TH FLOOR & 461505.658 & 457470.301 \\
\hline 3RD FLOOR & 467988.432 & 458314.251 \\
\hline 2ND FLOOR & 485210.613 & 457718.673 \\
\hline 1ST FLOOR & 402761.589 & 342880.242 \\
\hline GROUND & & \\
\hline FLOOR & 528667.468 & 407112.232 \\
\hline STILT & 1747716.785 & 1257035.574 \\
\hline FOUNDATION & 0 & 0 \\
\hline
\end{tabular}

Result: from the table it is seen that the maximum stiffness is seen at between foundation and ground floor at stilt level which is the $1747716.785 \mathrm{KN}-\mathrm{m}$.

Published By:

Blue Eyes Intelligence Engineering and Sciences Publication

(C) Copyright: All rights reserved.

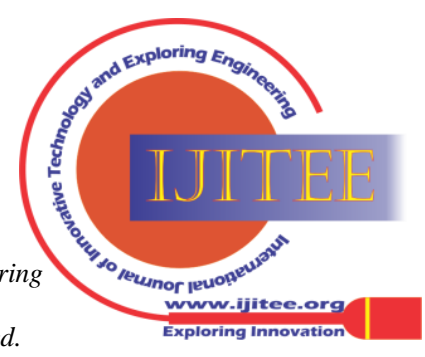


Dynamic Seismic Analysis and Design of R.C.C Multi Purpose Building (G+15) By using E-Tabs

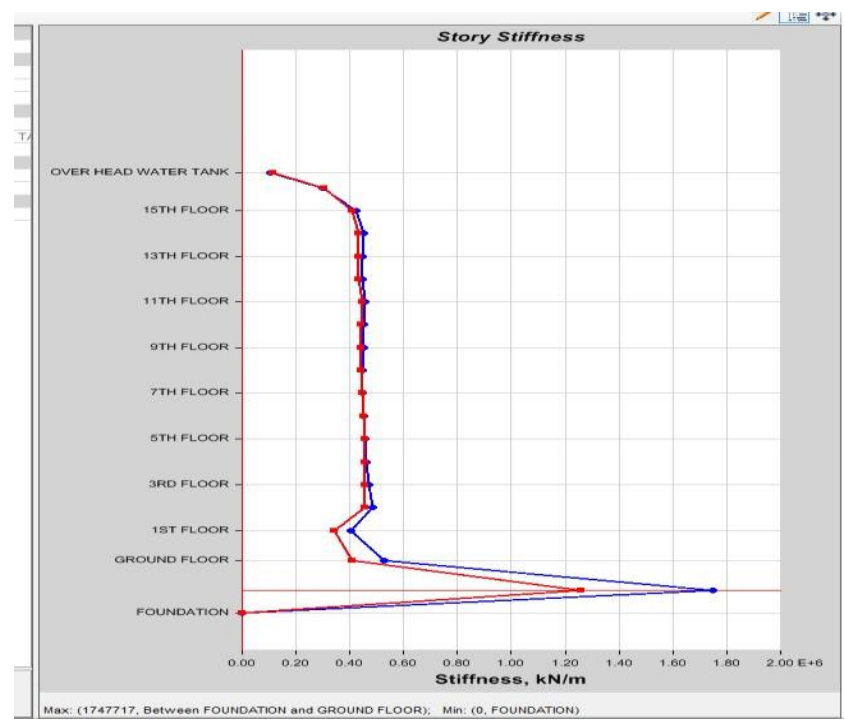

Graph 7: The graph showing the maximum stiffness occuring at stilt floor

\section{5 storey shear}

It is defined as the lateral force acting on each story in horizontal direction during earthquake, and the maximum lateral shear should always maximum at the base of the building which is termed as the Base shear. Maximum Story Shear for RS along X \& Y Axis The Shear force at the base of the structure so obtained is been plotted for $\mathrm{X}$ and $\mathrm{Y}$ direction.

Table 8. Storey shear of the structure

\begin{tabular}{|c|c|c|}
\hline \multirow[t]{2}{*}{ Story } & \multicolumn{2}{|c|}{ RS } \\
\hline & X-Dir & Y-Dir \\
\hline & $\mathrm{kN}$ & $\mathrm{kN}$ \\
\hline \multirow[t]{2}{*}{$\begin{array}{l}\text { OVER HEAD WATER } \\
\text { TANK }\end{array}$} & 34.7467 & 19.0145 \\
\hline & 34.7467 & 19.0145 \\
\hline \multirow{2}{*}{ TERRACE FLOOR } & 187.5282 & 102.6215 \\
\hline & 187.5282 & 102.6215 \\
\hline \multirow[t]{2}{*}{ 15TH FLOOR } & 321.1261 & 175.7305 \\
\hline & 321.1261 & 175.7305 \\
\hline \multirow[t]{2}{*}{ 14TH FLOOR } & 403.0815 & 220.5791 \\
\hline & 403.0815 & 220.5791 \\
\hline \multirow[t]{2}{*}{ 13TH FLOOR } & 453.1093 & 247.9559 \\
\hline & 453.1093 & 247.9559 \\
\hline \multirow[t]{2}{*}{ 12TH FLOOR } & 496.8741 & 271.9055 \\
\hline & 496.8741 & 271.9055 \\
\hline \multirow[t]{2}{*}{ 11TH FLOOR } & 546.2329 & 298.9162 \\
\hline & 546.2329 & 298.9162 \\
\hline \multirow[t]{2}{*}{ 10TH FLOOR } & 595.0718 & 325.6424 \\
\hline & 595.0718 & 325.6424 \\
\hline \multirow[t]{2}{*}{ 9TH FLOOR } & 633.7858 & 346.828 \\
\hline & 633.7858 & 346.828 \\
\hline \multirow[t]{2}{*}{ 8TH FLOOR } & 664.2049 & 363.4743 \\
\hline & 664.2049 & 363.4743 \\
\hline \multirow[t]{2}{*}{ 7TH FLOOR } & 696.3322 & 381.0553 \\
\hline & 696.3322 & 381.0553 \\
\hline \multirow[t]{2}{*}{ 6TH FLOOR } & 734.2589 & 401.81 \\
\hline & 734.2589 & 401.81 \\
\hline \multirow[t]{2}{*}{ 5TH FLOOR } & 770.9456 & 421.8862 \\
\hline & 770.9456 & 421.8862 \\
\hline \multirow[t]{2}{*}{ 4TH FLOOR } & 799.0286 & 437.2541 \\
\hline & 799.0286 & 437.2541 \\
\hline \multirow[t]{2}{*}{ 3RD FLOOR } & 822.4837 & 450.0895 \\
\hline & 822.4837 & 450.0895 \\
\hline \multirow[t]{2}{*}{ 2ND FLOOR } & 853.4781 & 467.0506 \\
\hline & 853.4781 & 467.0506 \\
\hline
\end{tabular}

\begin{tabular}{|l|r|r|}
\hline 1ST FLOOR & 903.5893 & 494.4731 \\
\hline GROUND FLOOR & 903.5893 & 494.4731 \\
\hline & 949.1208 & 519.3894 \\
\hline STILT & 949.1208 & 519.3894 \\
\hline & 956.7441 & 523.5611 \\
\hline FOUNDATION & 956.7441 & 523.5611 \\
\hline & 0 & 0 \\
\hline
\end{tabular}

Result: from the table it is seen that the maximum storey shear is abserved at bottom of the structure which is the structure which is $956.74 \mathrm{KN}$ in $\mathrm{x}$-direction and 523.56 in $\mathrm{y}$ direction.
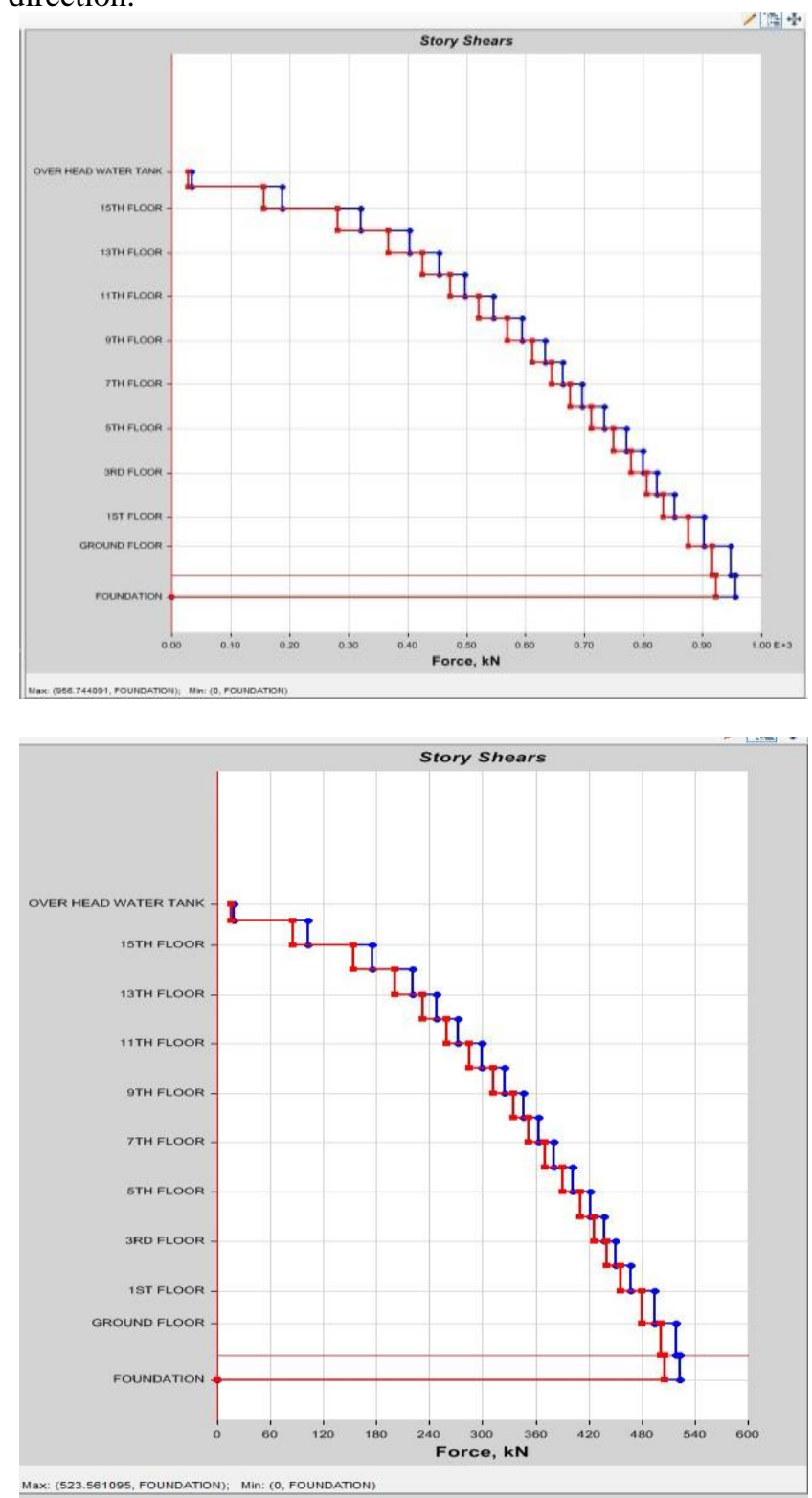

Graph 8\&9 : The graph showing the maximum storey shear at bottom of the structure

\subsection{Storey Drift}

story drift is the lateral displacement of one level relation to the level above or below

Published By:

Blue Eyes Intelligence Engineering and Sciences Publication

(C) Copyright: All rights reserved.

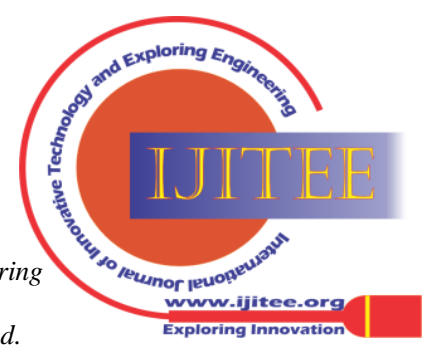


Table 9: storey drift of the structure

\begin{tabular}{|c|c|c|}
\hline Story & X-Dir & Y-Dir \\
\hline $\begin{array}{c}\text { OVER HEAD } \\
\text { WATER TANK }\end{array}$ & 0.00017 & 0.000093 \\
\hline $\begin{array}{c}\text { TERRACE } \\
\text { FLOOR }\end{array}$ & 0.000207 & 0.000113 \\
\hline 15TH FLOOR & 0.00025 & 0.000137 \\
\hline 14TH FLOOR & 0.000292 & 0.00016 \\
\hline 13TH FLOOR & 0.000332 & 0.000182 \\
\hline 12TH FLOOR & 0.000368 & 0.000202 \\
\hline 11TH FLOOR & 0.000403 & 0.00022 \\
\hline 10TH FLOOR & 0.000436 & 0.000239 \\
\hline 9TH FLOOR & 0.000465 & 0.000255 \\
\hline 8TH FLOOR & 0.000492 & 0.000269 \\
\hline 7TH FLOOR & 0.000516 & 0.000282 \\
\hline 6TH FLOOR & 0.000539 & 0.000295 \\
\hline 5TH FLOOR & 0.000558 & 0.000306 \\
\hline 4TH FLOOR & 0.000573 & 0.000314 \\
\hline 3RD FLOOR & 0.000582 & 0.000319 \\
\hline 2ND FLOOR & 0.000583 & 0.000319 \\
\hline 1ST FLOOR & 0.000567 & 0.00031 \\
\hline GROUND FLOOR & 0.000455 & 0.000249 \\
\hline STILT & 0.000192 & 0.000105 \\
\hline FOUNDATION & 0 & 0 \\
\hline
\end{tabular}

Result: from the table it is seen that the maximum Storey drift is abserved at first floor of the structure which is the 0.00066 For X-Direction

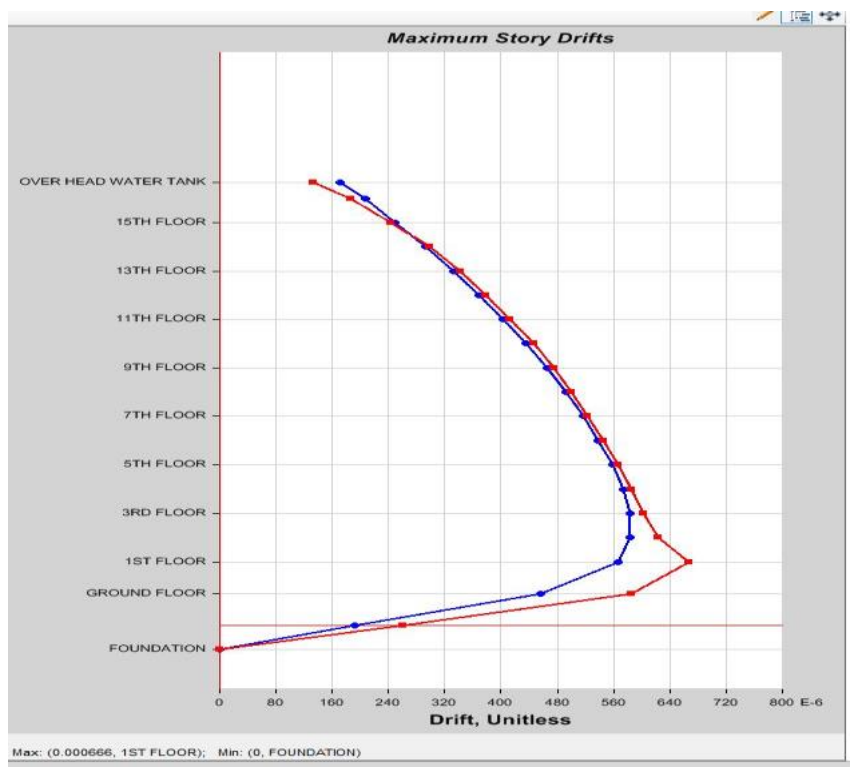

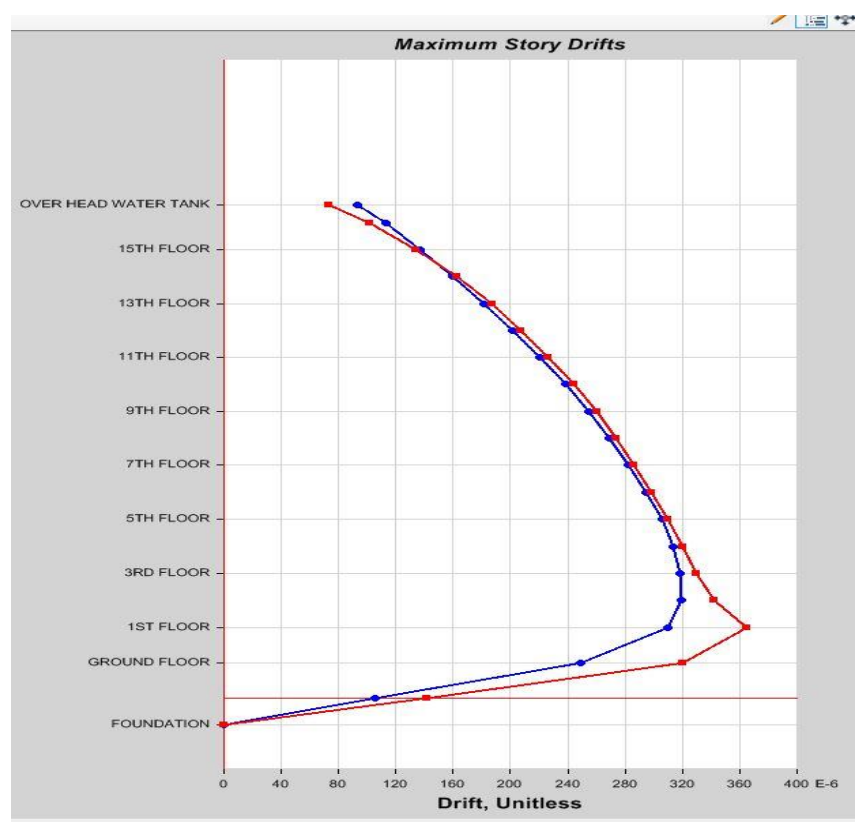

Max: (0.000365, 15T FLaOR); Min: (0, FOUNDATION

Graph 10 \& 11: The graph showing the maximum storey drift

\section{CONCLUSIONS}

In the project report a structural model is considered where in a model is subjected to wind and seismic loads along with their corresponding behaviours and results are extracted and interpreted. Various parameters such as displacements, storey drifts, storey force, storey Stiffness, and base shear have been considered. Hence from the obtained results the following conclusions are drawn,

1. Maximum lateral storey displacement occurs at terrace floor level of the structure model.

2. Maximum Storey drift usually occurs at mid height level and goes on decreasing from mid height towards roof level.

3. As the height of the building increases storey acceleration also increases and is also directly proportional to the seismic intensity.

4. The seismic forces are more concentrated at the base of the building hence the resistive Storey force by the building will be more at the lower storey.

5. As the seismic intensity increases the base shear of the building also increases correspondingly.

6. It is clear that as the seismic intensity increases the response of the building varies accordingly.

7. The seismicity/ the resistive force of the building against the seismic force is directly proportional to the intensity of the earthquake as the intensity increases seismicity of the building increases proportionally.

8. As the seismicity of the building increases care should be engaged by the structural engineers to oppose the seismic energy and to safe guard the building.

9. The maximum displacement is occuring at top of the structure at over head tank which is $6.925 \mathrm{~mm}$

10. The maximum lateral loas is occuring at 15 th floor which is $154.2959 \mathrm{KN}$ for $\mathrm{x}$-direction and 158.0122 $\mathrm{KN}$ for $\mathrm{y}$-direction

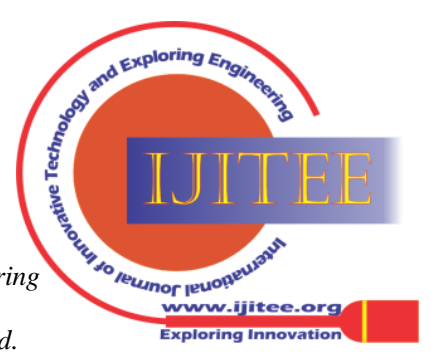


11. The maximum overturning moment is occuring at foundation level which is the $31934.3626 \mathrm{KN}-\mathrm{m}$ at $\mathrm{y}$ direction

12. The maximum stiffness is seen at between foundation and ground floor at stilt level which is the $1747716.785 \mathrm{KN}-\mathrm{m}$

13. The maximum storey shear is abserved at bottom of the structure which is the structure which is 956.74 $\mathrm{KN}$ in $\mathrm{x}$-direction and 523.56 in y-direction.

14. That the maximum Storey drift is abserved at first floor of the structure which is the 0.00066 For $\mathrm{X}$ Direction.

\section{REFERENCE}

1. Murty.CVR and Jain.SK " A Review of IS-1893-1984 Provisions on Seismic Design of Buildings ". The Indian concrete journal, Nov.1994.

2. Sarkar, P. Agarwal , R and Menon , D." Design of beam ,column joints under Seismic loadings " A review, Journal of structural engineering SERC, Vol.33.No.6.Feb.2007

3. Reddell, R and Llera , J.C.D.L " Seismic analysis and design " Current practise and Future trends. Eleventh World Conference on earthquake, engineering Mexico.

4. IS-456-1978 and IS-456-2000."Indian Standard of code and practise for plain and Reinforced concrete "Bureau of Indian Standards ,New Delhi-2002

5. IS-875-1987. "Indian Standard code of practise for structural safety loadings standards part-1,2 " BIS , New -Delhi

6. SP-16-1980-Design Aids for Reinforced concrete to IS-456-1978BIS, New Delhi.

\section{AUTHORS PROFILE}

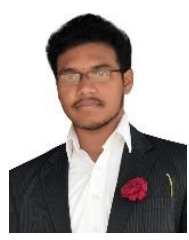

Mr. T.G.N.C. Vamsi Krishna, is a Post graduate in Structural Engineering and present working as Assistant professor in Chalapathi Institute of Engineering and Technology, Lam , Guntur

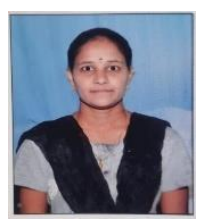

Miss. V.Amani, is studying final year of Bachelor of Technology in Chalapathi Institute of Engineering and Technology, Lam , Guntur

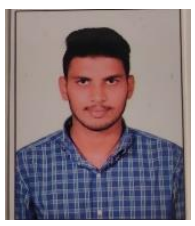

Mr. P.S. Sunil Kumar, is studying final year of Bachelor of Technology in Chalapathi Institute of Engineering and Technology, Lam, Guntur

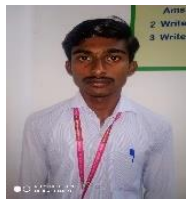

Mr. CH. Naveen Kumar, is studying final year of Bachelor of Technology in Chalapathi Institute of Engineering and Technology, Lam, Guntur

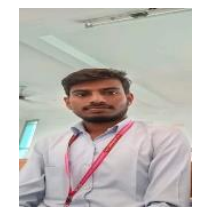

Mr. M.Srinivas, is studying final year of Bachelor of Technology in Chalapathi Institute of Engineering and Technology, Lam, Guntur

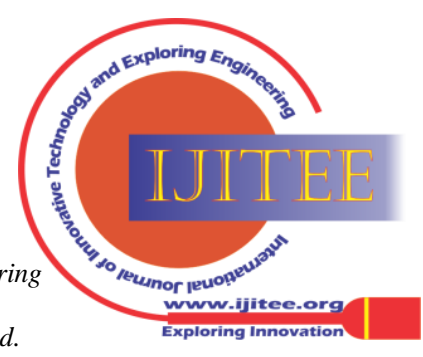

